\title{
Economic Assessment of Integrated Fish Farming (Fish- Rice-Piggery) in Sierra Leone
}

\author{
Olapade Olufemi Julius ${ }^{1,}$, , Alimamy Turay ${ }^{1}$, Momoh Rashid Raymond² \\ ${ }^{1}$ Department of Aquaculture and Fisheries Management - School of Forestry and Horticulture, Njala University, Njala, Sierra Leone \\ ${ }^{2}$ Department of Extension and Rural Sociology School of Agriculture, Njala University, Njala, Sierra Leone
}

Email address:

fem66@hotmail.com (O. O. Julius), ojulius@njala.edu.sl(O. O. Julius),6532rashid@gmail.com (M. R. Raymond), raymondmomoh2006@yahoo.com (M. R. Raymond)

\section{To cite this article:}

Olapade Olufemi Julius, Alimamy Turay, Momoh Rashid Raymond. Economic Assessment of Integrated Fish Farming (Fish-Rice-Piggery) in Sierra Leone. Agriculture, Forestry and Fisheries. Vol. 4, No. 3, 2015, pp. 87-94. doi: 10.11648/j.aff.20150403.12

\begin{abstract}
The present study evaluates the profitability and environmental effect of integrated fish cum rice and piggery production at Njala University, Sierra Leone. The research carried out between June and November, 2014 consists of the pigsty $(2.5 \mathrm{~m} \times 11 \mathrm{~m})$, a maggoty and integrated pond $\left(395.2 \mathrm{~m}^{2}\right)$ sown with $0.94 \mathrm{~kg}$ NERICA 19 rice at spacing of $20 \mathrm{~cm}$ inter - rows and $5 \mathrm{~cm}$ intra - rows. The pond was stocked with Clarias gariepinus juveniles (mean weight $25.6 \pm 1.78 \mathrm{~g}$ ) at the density of 4.8fish per $\mathrm{m}^{2}$. Water quality parameters viz., temperature, $\mathrm{pH}$, Dissolved oxygen, $\mathrm{NO}_{3}-\mathrm{N}_{,} \mathrm{NH}_{3} / \mathrm{NH}_{4}$, hardness and alkalinity were determined in the pond and were found to be within the recommended range for the culture of tropical fish. Economic analysis of the adaptive research gave a negative incremental benefit and Net Present Value (NPV) in both the first and second year of production. The sensitivity analysis evaluation shows that the enterprise is fairly sensitive to price fluctuation (-46.02\%) and highly sensitive to survival rate of the fish and the scale of production of the pigs. Increasing scale of production and selling at market price will greatly enhance profitability and short term payback of costs.
\end{abstract}

Keywords: Profitability, Integrated Aquaculture, Water Quality, Njala University, Sierra Leone

\section{Introduction}

Hunger and malnutrition are among the foremost problems facing the majority of the world's poor and needy, and this continue to dominate the health of the world's poorest nations [1]. About $30 \%$ of humanity, including infants, children, adults and elderly within the developing world, are known to be currently suffering from one or more of the multiple forms of malnutrition [1]. Aquaculture (the farming of fish, other aquatic animals and plants) is considered as one of the world's global food production systems that can effectively be used to tackle the problems of malnutrition and poverty particularly in the developing countries [2]. Coastal and inland fisheries are stagnating or declining in the sub-region, which presents a real concern in terms of fish supply and food security. The development of aquaculture appears as a possible solution for this growing supply gap in the future. Integrated aquaculture which link aquaculture to conventional farming systems will be the most appropriate weapon to fight hunger and poverty in sub Saharan Africa. The development of such systems has been driven by different needs in different parts of the world, including a desire to improve food security on small, subsistence family farms; or to minimize pollution and use valuable resources (such as water) more efficiently and effectively. Integrated agriculture aquaculture system (IAAS) practices were established long ago in many Asian countries for subsistence purposes, but are increasingly being developed for more commercial, income generating purposes in both Asia and developed "Western" countries. The practice is however quite a new way of farming in Africa. The principle behind integrated agri-aquaculture business is the maximal use of all available land and water resources. Integrated pig/fish/rice production is a promising way of making the most of a small farmer's land and labour. Economic studies have shown that traditional production system is wasteful and unprofitable due to poor feed conversion, high mortality rates, low reproductive rates and final products [3]. It is now established that integrated fish cum livestock farming is a good strategy that can be 
adopted by small scale farmers in developing countries to boost farm yield and returns. Similarly, integrated farming is a way of ensuring stability in the production processes spreading the risk of production over several activities. Since livestock and fish production are not usually characterized by co-variant risks, the farmer is able to stabilize inter temporal flow of daily income. Moreover, integrated farming maintains environmental friendliness by facilitating productive use and recycling of wastes [4].The multi-stage utilization of feedstuffs and fertilizer makes it possible to supply the community with more produce and to increase the income for the fish farm as well. The importance of integrated livestock/piggery, rice and fish production system has begun to be more appreciated. This present study seeks to evaluate and document information on the interplay of components of the integrated aquaculture system especially in relation to returns on investment, sustainability issues, and utilization of resources within the system and the impact of the research innovation on the environment.

\section{Materials and Methods}

\subsection{Description of the Study Area}

The research was conducted at Njala University fish farm in Moyamba district, southern province, Sierra Leone (Fig. 1). Sierra Leone is located on the west coast of Africa, between the $7^{\text {th }}$ and $10^{\text {th }}$ parallels north of the equator. The country is bordered by Guinea to the north and northeast, Liberia to the south and southeast, and the Atlantic Ocean to the west. The country has total area of $71,740 \mathrm{~km}^{2}\left(27,699 \mathrm{~m}^{2}\right)$ divided into a land area of $71,620 \mathrm{~km}^{2}\left(27,653 \mathrm{~m}^{2}\right)$. The country has four distinct geographical regions; coastal Guinean mangroves, the wooded hill country, an upland plateau, and the eastern mountain. Eastern Sierra Leone is an interior region of large plateaus interspersed with high mountains, where mount Bintumani rises to $1,948 \mathrm{~m}(6,391 \mathrm{ft})$ [5]. The climate of $\mathrm{Njala}$ is mainly tropical and has distinct dry and rainy seasons. Daily mean temperature ranges from $21{ }^{\circ} \mathrm{C}$ to $23^{\circ} \mathrm{Cfor}$ the greater part of the dry season. The vegetation consists of farm bush, grassland and inland valley swamps.

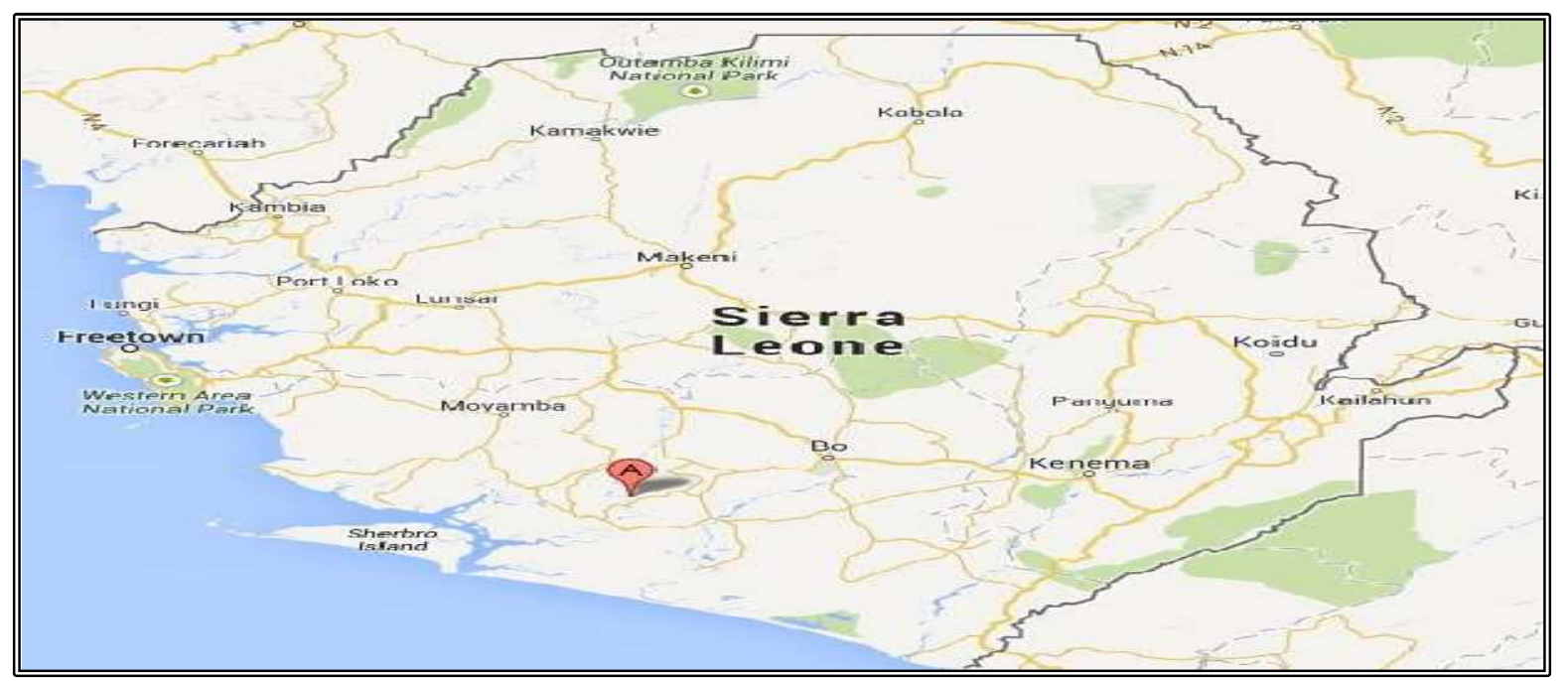

Figure 1. Map of Sierra Leone Showing location of Njala University inMoyamba.

\subsection{Experimental Design}

The experiment lasted six months (June - November, 2014). The adaptive research platform consisted of the pigsty $(2.5 \mathrm{~m} \times 11 \mathrm{~m}$ in dimension) partitioned into three units with wastes discharge channels (Plate 1) and a maggoty made of bush stick and corrugated iron sheet (Plate 2). The integrated pond has a surface area of $395.2 \mathrm{~m}^{2}$ which was divided into fish refuge $\left(208.2 \mathrm{~m}^{2}\right)$ and rice paddy platform $10 \mathrm{~m} \times 18.7 \mathrm{~m}$ $\left(187 \mathrm{~m}^{2}\right)$ (Plate 3).

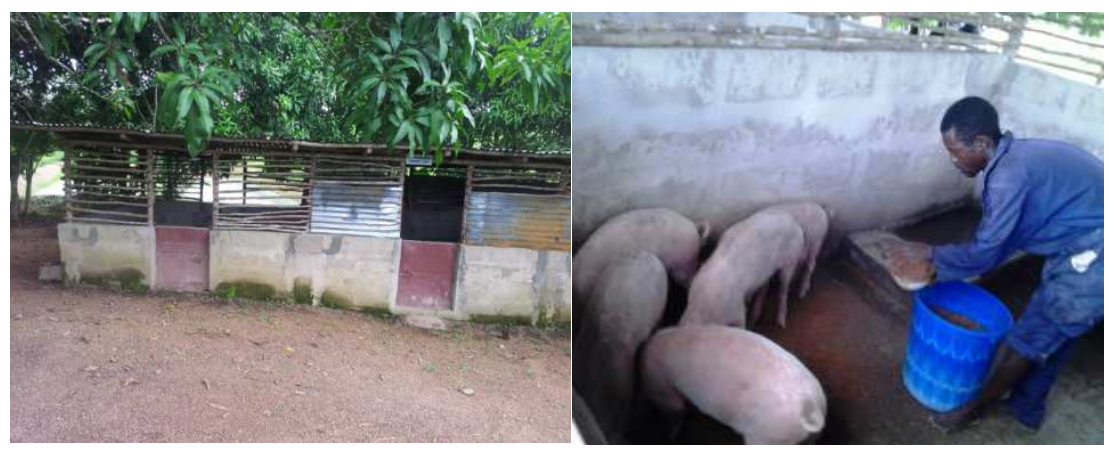

Plate 1. The pigsty and the piggery (feeding time). 


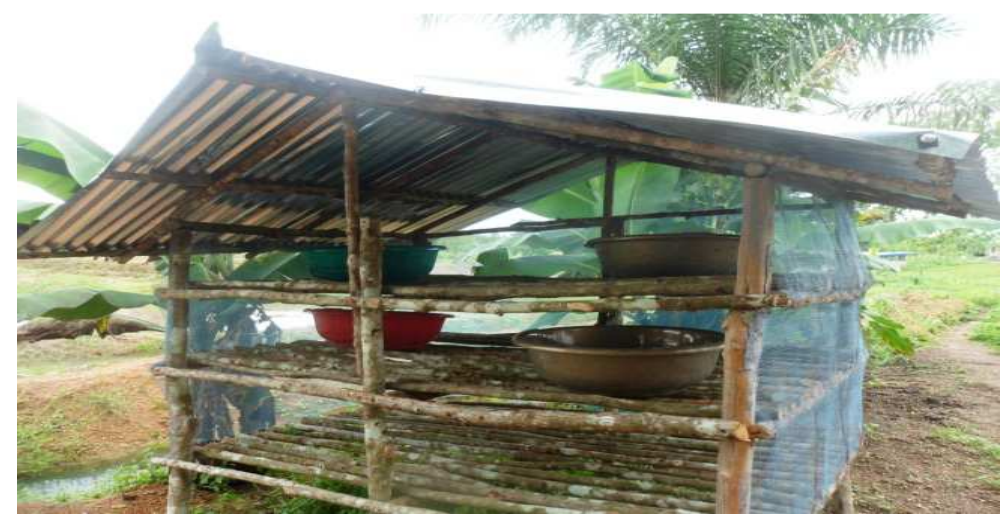

Plate 2. The maggoty.

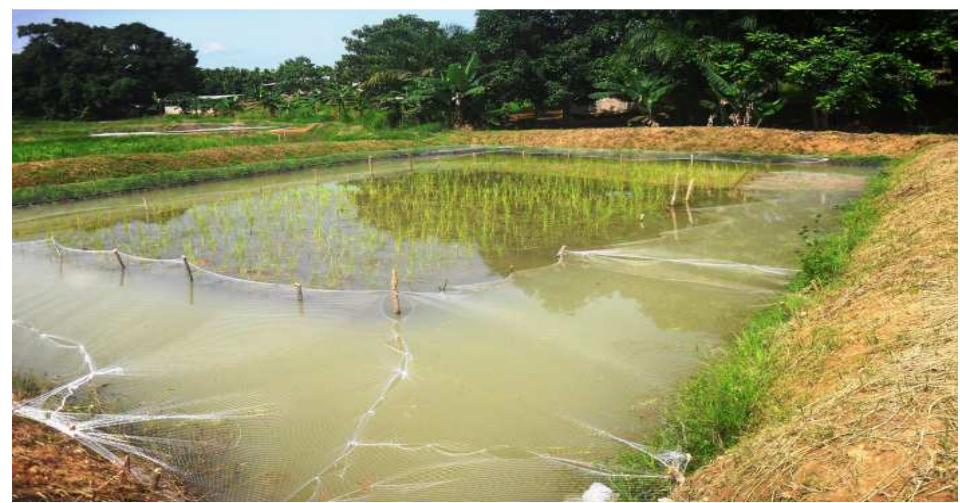

Plate 3. The paddy field.

\subsection{Cultural Practices}

Lowland NERICCA 19 rice $(0.94 \mathrm{~kg})$ was nursed for transplanting into the rice paddy at a spacing of $20 \mathrm{~cm}$ inter rows and $5 \mathrm{~cm}$ intra rows. The rice field was fertilized with organic manure at recommended rate $(150 \mathrm{~kg}$ fresh manure/ha/day). This was done twice in a month to avoid the problem of overloading that could lead to water chemical imbalance. Water in the integrated pond was kept low at the level of the paddy to prevent the young seedlings from logging by simply lowering the stand pipe at the outlet. Weed was manually removed twice a month (rouging) (Plate 4).

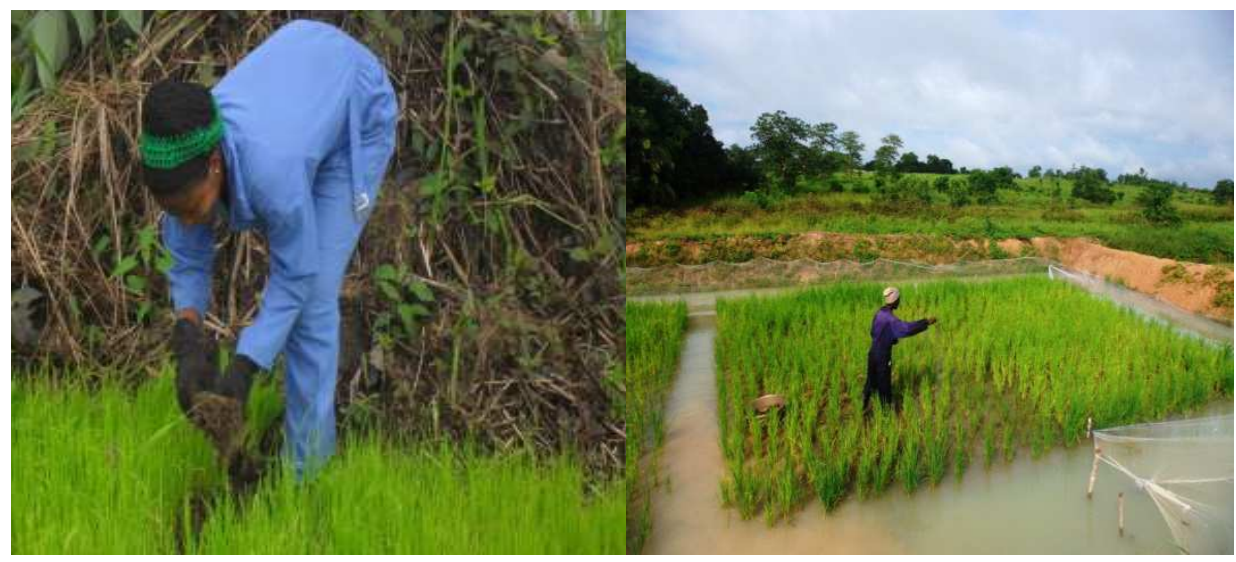

Plate 4. $\boldsymbol{a}$ and $\boldsymbol{b}$. Cultural practices in the paddy field.

\subsection{Piggery Production}

One in-gilt and eight weaners were housed in the pigsty (4 weaners per unit while the in-gilt was isolated). The animals were washed every three days and fed to satiation once a day. Random weighing was done every month. The pig feed consists of palm kernel cake, salt, fish scraps, rice bran, corn meal and a little addition bone meal. The animals were also fed regularly with leafy vegetables and fruits such as Ipomoea reptans (gogodi) Alternanthera braziliana, pawpaw leaves and fruits (this contain piperazine which serves as dewormer). Mango fruits were also given to them when available. Wounds sustained through wall rubbing were treated with Gentian Violet and disinfection was carried out 
with Dettol and Izal.

\subsection{Fish Culture}

Clarias gariepinus juveniles mean weight $25.6 \mathrm{~g}$ obtained from Magbosie village flood plains was stocked at a density of 4.8 fish per $\mathrm{m}^{2}$. The fish were initially acclimated for three days without food so as to adjust them to taking imported expanded pellets ( $45 \%$ crude protein). The fish were fed at $5 \%$ of body weight and feeding was adjusted every month to attune to weight gain. Feeding was supplemented with maggots generated from the poultry manure every one week. Extruded sinking pellets were made locally to reduce the high cost of imported diet which would make it impossible for local farmers to adopt the innovation. The culture period lasted six months.

\subsection{Maggot Production}

Wastes generated in the poultry house was divided and bagged in polyethylene with the second portion poured into plastic bowls as shown in the plate 5 . The wastes were thereafter wetted with water and layered with handful of rice bran for ease of maggot production and were left in the open in the maggoty for the blow flies to have easy access to them. Big brown colored larvae of the blow flies which are rich in protein are produced in sufficient quantities after seven days. These are sieved, weighed and poured into the pond for consumption by the fish. Digested wastes left after maggots have been removed are used as fertilizer for the rice paddy and also for pond productivity.

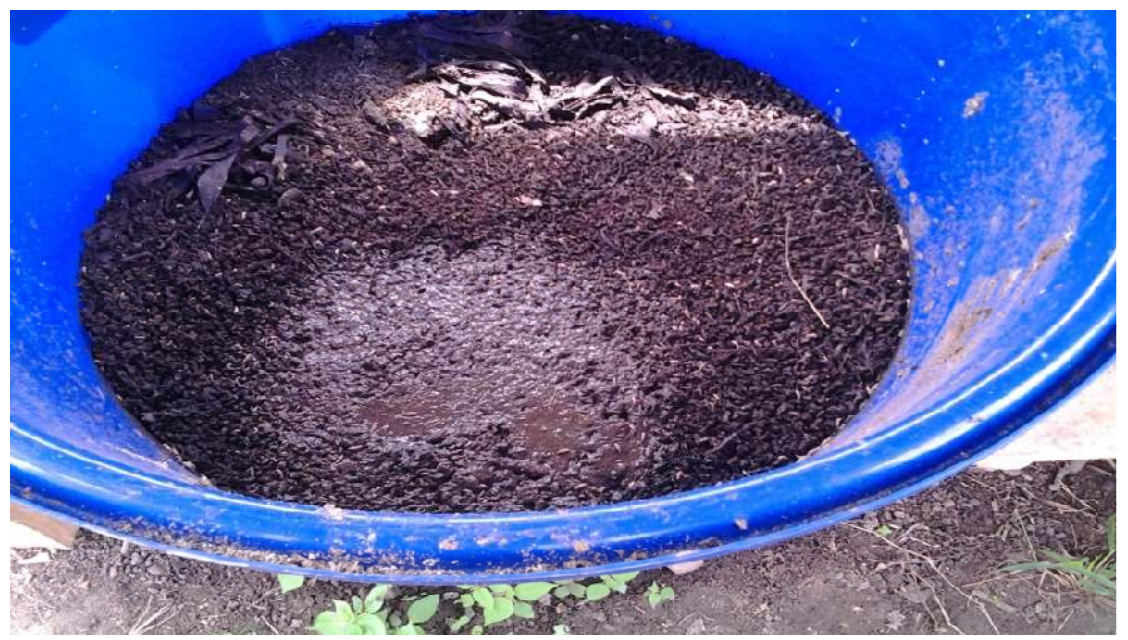

Plate 5. Festering Maggots.

\subsection{Water Quality Assessment}

Water quality parameters measured bi-weekly include: Dissolved oxygen, water temperature, $\mathrm{pH}$, water hardness, water alkalinity, ammonia, nitrate, BOD and nitrite. These parameters were determined using Jenway analytical probes and Pondlab multi-parameter kits. Water samples were collected at three different points - Point A (water inlet point); Point B (mid - pond close to the paddy platform) and Point C (outlet point). Three samples were collected in cleaned $600 \mathrm{ml}$ water bottles per sampling points. The water samples were preserved with one percent concentrated $\mathrm{HNO}_{3}$ and kept in the refrigerator at $4^{\circ} \mathrm{C}$ prior to analysis in the laboratory.

\subsection{Statistical Analysis}

Measure of central tendency (mean and standard deviation) and one-way analysis of variance (ANOVA) at $\mathrm{P}=0.05$ were used to analyze the results of the water quality variables measured in the adaptive research pond. Significant differences were separated using the least significant difference (LSD).

\subsection{Economic Analysis}

Estimation of production costs, and gross revenues, cash flow, sensitivity analysis of the project, gross merging and benefit - cost ratio were evaluated using the formulae below.

Incremental benefit $=$ Revenue - Costs

Discounted costs $=$ Discount factor $(15 \%)$ multiply by Costs

Discounted revenue $=$ Discount factor $(15 \%)$ multiply by Revenue

Net Present Value at $15 \%=$ Discounted revenue Discounted costs

Discounted factor at $15 \%$ was calculated as follows

$$
\begin{aligned}
& \text { Year } 1=1 \div(1+15 \%)^{1} \\
& \text { Year } 2=1 \div(1+15 \%)^{2} \\
& \text { Year } 3=1 \div(1+15 \%)^{3}
\end{aligned}
$$

Sensitivity Analysis of the project was estimated as = Total NPV $(3$ years $) * 100$

Total Discounted Costs (3 years)

Net profit $=($ Gross revenue $)-$ Total operating costs $)$

Gross profit margin $=($ Gross profit $) \div($ Gross revenue $)$

Payback period $=($ Total capital cost $) \div($ Net profit $)$

Benefit - Cost Ratio $=$ Discounted Revenue $\div$ Discounted Costs 


\section{Results}

\subsection{Physico-chemical Parameters}

The results of the water quality parameters evaluated in this study are presented in Fig2, 3 and 4.Mean surface water temperature ranged from $28 \pm 0.15-28.8 \pm 0.51^{\circ} \mathrm{C}$ in the integrated pond. The highest and lowest mean water temperature values were obtained in June and November respectively and were not significantly different $(\mathrm{p}<0.05)$. $\mathrm{pH}$ value of $6.2 \pm 0.32$ obtained in November was higher than $6.1 \pm 0.26$ recorded in October and $5.8 \pm 0.17$ obtained in July. The highest value of $6.73 \pm 0.25$ was recorded in the month of June while July recorded the lowest $p \mathrm{H}$ value.
Mean dissolved oxygen values of $6.70 \pm 0.20 \mathrm{mg} / \mathrm{L}-7.09 \pm$ $0.18 \mathrm{mg} / \mathrm{L}$ were recorded for the study. The highest value was obtained in July while the least was obtained in September. These mean values were however not below the critical level of $4 \mathrm{mg}^{1}$ for fish culture in the tropics. BOD values obtained throughout the sampling period ranged from $3.07 \pm 0.12$ $\mathrm{mg} / \mathrm{L}-3.93 \pm 0.06 \mathrm{mg} / \mathrm{L}$. These values showed no significant difference $(\mathrm{p}<0.05)$ with locations and months of sampling. Alkalinity and general hardness values were constant throughout the period of study $(35 \mathrm{mg} / \mathrm{L}$ and $54 \mathrm{mg} / \mathrm{L}$ respectively). Nitrate - Nitrogen and Ammonia/Ammonium $\left(\mathrm{NH}_{3} / \mathrm{NH}_{4}\right)$ was not detected in the ambient water of the integrated pond which is an indication of low organic loading.

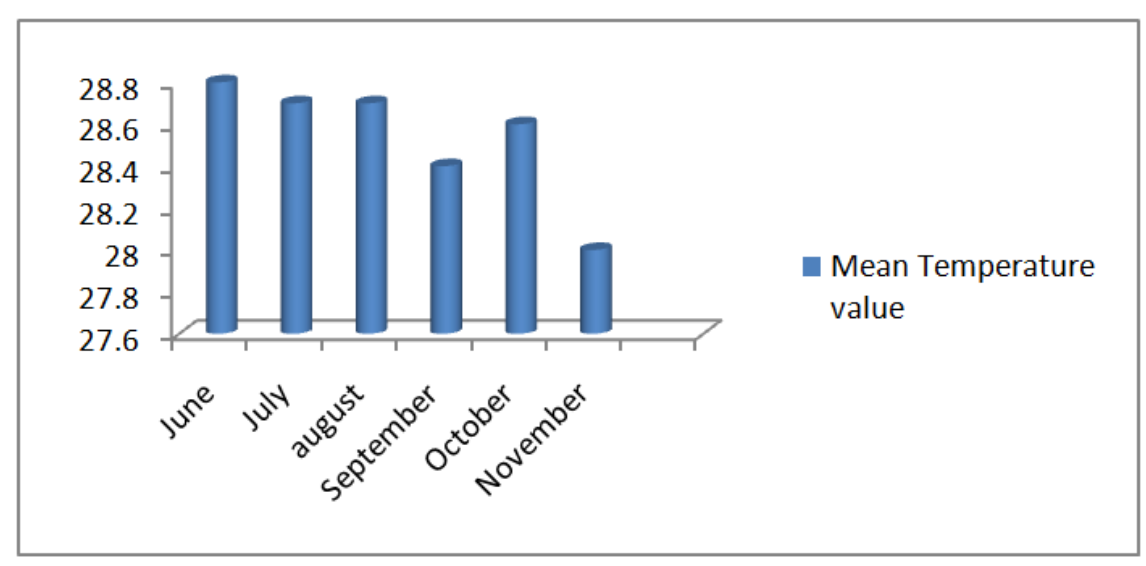

Figure 2. Mean temperature recorded for the study.

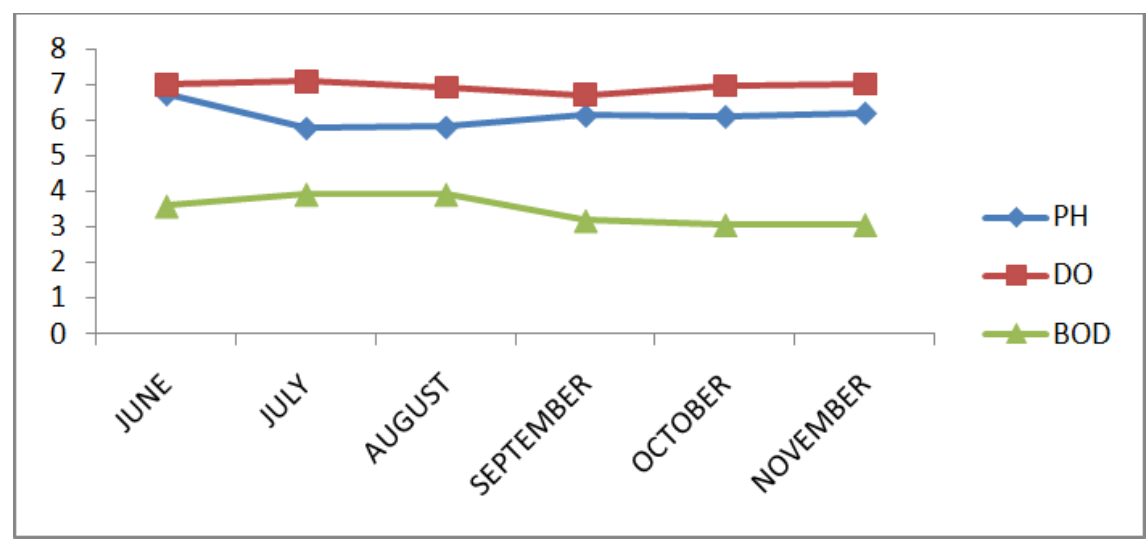

Figure 3. $p H, D O$ and $B O D$ recorded for the study.

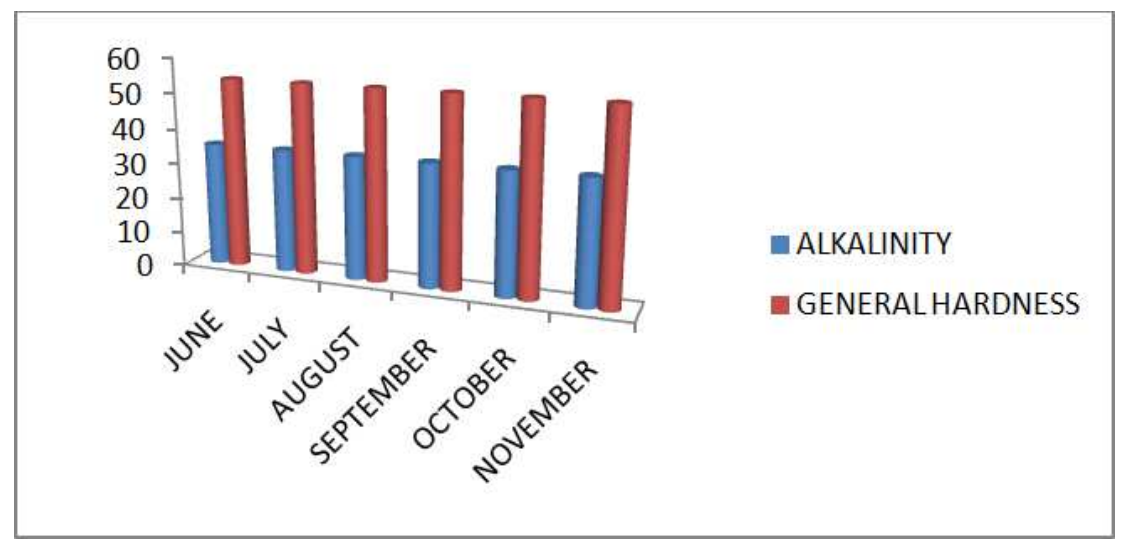

Figure 4. Alkalinity and general hardness recorded for the study. 


\subsection{Economic Performance of the Study}

Table 1 presents the cost and revenue of the investment in the first year. The cash flow analysis presented in table 2 . The Net Present Value (NPV) of the project is Le 4,231,351.52 (US\$ 950.87) while the benefit/cost ratio is calculated as Discounted revenue/Discounted costs $=0.54$. The assumption that a project is feasible when NPV is positive and benefit/cost ratio is greater than 1 holds for this projection.

\subsection{Sensitivity Analysis (Uncertainty Determination)}

This a measure for testing risk in investment feasibility especially the influence of unstable prices of inputs on costs of project. For this project the sensitivity is:

NPV at $15 \%$ discount rate $=$ Le $-4,231,351.52$

Total Costs Present Values (CPV) at $15 \%$ discount rate $=$ Le $9,195,431.52$

$$
\text { Senstivity }=\frac{-4231351.52 \times 100}{9195431.52}=-46.02 \%
$$

This analysis assumed that costs of this project are highly sensitive to price fluctuations and therefore the investment should be properly managed achieve a positive incremental benefit and Net Present Value (NPV).

Table 1. Budget-Costs and Revenues.

\begin{tabular}{|c|c|}
\hline \multicolumn{2}{|c|}{$1^{\text {st }}$ year of operation ( $\left(1^{\text {st }}\right.$ production cycle $)$} \\
\hline \multicolumn{2}{|l|}{ Fixed capital expenses } \\
\hline construction of piggery house & Le $8,363,474$ \\
\hline 2. construction of maggoty house & Le 70,000 \\
\hline 3. construction of fish pond & Le $2,221,234$ \\
\hline 4. Equipment & Le $1,280,000$ \\
\hline \multicolumn{2}{|l|}{ Operating Expenses } \\
\hline \multicolumn{2}{|l|}{ 1. Stock } \\
\hline Purchasing of pigs & Le $1,300,000$ \\
\hline Fish seeds (1000 Clarias gariepinus) & Le $1,000,000$ \\
\hline Rice seeds (NERICA 19) & Le 20,000 \\
\hline \multicolumn{2}{|l|}{ 2. Labor } \\
\hline \multirow{2}{*}{\multicolumn{2}{|c|}{$\begin{array}{l}\text { Permanent and Hired } \\
\text { 3. Feed }\end{array}$}} \\
\hline & \\
\hline Piggery feeds & Le $2,500,000$ \\
\hline \multirow{2}{*}{\multicolumn{2}{|c|}{$\begin{array}{l}\text { Fish feed } \\
\text { 4. Others }\end{array}$}} \\
\hline & \\
\hline Chemical lime and disinfectants & Le 50,000 \\
\hline Drugs and disinfectants & Le 500,000 \\
\hline \multicolumn{2}{|l|}{ Summary of cost } \\
\hline Fixed capital & Le $11,934,708$ \\
\hline Operating expenses & Le $8,964,000$ \\
\hline Total & Le $20,898,708$ \\
\hline \multicolumn{2}{|l|}{ Revenue } \\
\hline Rice & Le 70,000 \\
\hline Fish & Le $4,400,000$ \\
\hline Pigs & Le $6,812,000$ \\
\hline Total & Le $11,282,000$ \\
\hline
\end{tabular}

Table 2. Cash flow analysis for a years (1 production cycle).

\begin{tabular}{lllllllll}
\hline Cycle & Costs & revenue & $\begin{array}{l}\text { Incremental } \\
\text { Benefit (1) }\end{array}$ & $\begin{array}{l}\text { Discount Factor at } \\
\mathbf{1 5 \%} \mathbf{( 2 )}\end{array}$ & $\begin{array}{l}\text { Net Present Value } \\
\text { at 15\% (3) }\end{array}$ & $\begin{array}{l}\text { Discounted Costs } \\
\text { (4) }\end{array}$ & $\begin{array}{l}\text { Discounted } \\
\text { Revenue (5) }\end{array}$ \\
\hline 1 & $20,898,708$ & $11,282,000$ & $-9,616,708$ & 0.44 & $-4,231,351.52$ & $9,195,431.52$ & $4,964,080$ \\
\hline
\end{tabular}

\section{Discussion}

The physico-chemical parameters of the study site are within the recommended level for the survival of fish and other aquatic biota [6]. Physico-chemical parameters of water body serve as measure of water quality [7]. Changes in the intensity of rainfall are known to affects physico-chemical parameters of water [8]. Water quality in fish ponds is affected by the interactions of several chemical components. Carbon dioxide, $\mathrm{pH}$, alkalinity and hardness are interrelated and can have profound effects on pond productivity, the level of stress and fish health, oxygen availability and the toxicity of ammonia as well as that of certain metals [9].The $\mathrm{pH}$ of the integrated fish pond with the exception of June that recorded 6.73 was below the recommended level for the survival and performance of tropical fish species and also below the range associated with most natural waters [10]. The low $\mathrm{pH}$ could be attributed to the component of the soil on which the pond was constructed. $\mathrm{NO}_{3}-\mathrm{N}$ and $\mathrm{NH}_{3} / \mathrm{NH}_{4}$ were not detected in the ambient water.

\subsection{Economic Performance of the Study}

The Net Present Value and the benefit/cost ratio calculated for the business does not conform to the assumption that a project is feasible when NPV is positive and benefit/cost ratio is greater than 1 . The NPV of this study is negative (-Le $4,231,351.52)$ and the benefit - cost ratio is below $1(0.54)$. The sensitivity analysis of the study was negative (-46.02\%). The negative NPV with the benefit - cost ratio of the enterprise that was below 1 is a clear pointer to the fact that the investment was not profitable in the first year due to so many factors. These factors include the high initial capital outlay especially in the construction of the pigsty and the paddy pond; the scale of production of both the piggery and the integrated pond which is assumed to be highly germane to the profitability of the investment. Other factors that require special attention in order for the investment to be profitable are physical factors; which include the environmental conditions of the farm area. There is the need to improve on the water quality parameters of the integrated fish pond especially the $\mathrm{pH}$, dissolved oxygen, alkalinity and hardness. These factors could be limiting to the productivity of the pond. Yields form the investment can be determined by either of topographies (sources of water supply, water quality, type of soil and weather), types of fish pond, and farm sizes. Yields are known to be sensitive to physical factors, farm size, farm type and stocking rate. Besides the stocking rate, types of fish stocked also determine the returns on 
investment. In this study fish stocked were sourced from the wild since there was no single fish hatchery in Sierra Leone. Importing fish from abroad attract a lot of money and immigration restrictions. Consequently, the high mortality recorded as a result of the source of the fish grossly affected the revenue by reducing the overall incremental benefit of the investment. Survival rate determines the quantity produced at the end of the production period [11]. Increasing mortality rates leads to low survival rate and thus lower yields. Higher yields coupled with good prices are needed to increase revenue and thus profitability.

The average total cost of Le 20,898,708.00 (US\$4,860.16) was expended in the first production cycle of the first year and gross revenue of Le 11,282,000 (US\$ 2,623.72) was earned. This result explained the fact that integration of rice cum fish and piggery production is capital intensive and that the business will not recoup its cost under the circumstances in which it was carried out. Running a three years cash flow analyses and calculating the internal rate of return (IRR) of the investment will clearly throw light on the actual payback period which is presumed to be two year provided all the bottle necks are circumvented.

The findings of this study show disparity in pricing of the farm produce. In the capital city (Freetown), a pound of pork sells for Le 11,000 as against Le 7,000 that it was sold to the university community - a big gap of Le 4,000 and this could have contributed to up the revenue. In Nigeria, a kilogram of catfish sells for 500 (US\$ 3.03) farm gate prices whereas it was sold at Le 10,000 (US\$ 2.25) in Sierra Leone. Increasing the selling prices of both the pork and the fish to match current market price elsewhere will make the investment profitable and highly attractive to farmers. For the present study to break even there is the need to increase the stocking density of the fish to $9.8 \mathrm{fish} / \mathrm{m}^{2}$. The rearing period of the pigs should equally be shortened to six months to accommodation two cycles of production for the pig per annum. This will increase the revenue base of the study without significantly affecting the variable costs especially when the final products are sold at the existing marketing price which was far higher than what was used in this study.

\subsection{Conclusions}

The economic benefit of integrated fish farming is enormous. It contributes immensely to the economic empowerment of families' especially in rural communities and enables the farmer to be productive all the year round provided the different components of the farming system are well utilized by the farmers to advantage. The findings of the study clearly showed that the venture will be profitable in the long run especially if the operating cost could be reduced through the supply of input locally. A range of public and private sector investments and initiatives are needed to realize the potential for the development of integrated fish farming especially in the area of supply of inputs such as fingerlings, feeds, seeds and other ancillaries. Public private partnerships offer potentially important opportunities for propoor agricultural development. Such collaborations have already contributed to food security in many developing countries.

It was also discovered that the price at which the pork and table fish were sold is below what is obtained in the urban cities. Therefore, if the price of the fish could be increased from Le 10,000 (US\$2.25) to Le 15,000 (US\$ 3.37) and the pork to Le 10,000 (US\$ 2.25) it will enhance quick profitability and early payback of invested cost and encourage farmers to adopt the innovation. To make the best out of the integrated fish farming investment, increasing the scale of production for pigs, rice and fish has been found to be related to increase profitability.

\section{Acknowledgement}

The authors greatly acknowledged CORAF/WECARD who through Poverty Eradication and Grassroots Empowerment through Sustainable Integrated Aquaculture Development: Fish cum rice and Piggery production (Project Number: 03PA11) supported this adaptive research at the Department of aquaculture and Fisheries Management Njala University, Sierra Leone.

\section{References}

[1] World Health Organization, Malnutrition the global picture 2000 http://www.who.org.nut.welcome.htm

[2] A.G.J. Tacon, A.G.J, Increasing the contribution of aquaculture for food security and poverty alleviation. In: R.P. Subashinghe, P. Bueno, M.J. Philips, C. Hough, S.E, McGladdery and J.R. Arthur, Eds. Aquaculture in the Third Millennium. Technical Proceedings of the conference on Aquaculture in the Third Millennium, Bangkok, Thailand, 20 -25 February 2000. Pp. 63 - 72. NACA, Bangkok and FAO, Rome 2001.

[3] A. Verhulst, Lessons from field experiences in the development of monogastric animal production. In: Mack, S. (Ed.), Strategies for sustainable animal agriculture in developing countries. Proceedings of the FAO expert consultation held in Rome, Italy, 10 - 14 December 1990. FAO Animal Production and Health Paper 107, 1993 pp. 261271(http://www.fao.org/DOCREP/004/TO582E/TO582EOO.h tm\#TOC.

[4] O. Amarasinghe, Some Economic Aspects of Integrated Livestock - Fish Farming in Sri Lanka. Integrated - Fish Production Systems: Proceedings of the FAO/IPT Workshop on Integrated Livestock - Fish Production Systems, $16-20$ December 1991, Institute of Advanced Studies, Universities Malaya, Kuala Lumpur, Malaysia 1992 ISBN 983 - 9576 - 16 $-\mathrm{X}$.

[5] S. Levert, Sierra Leone (Cultures of the World). Cavendish Square Publishing, New York, USA. ISBN 13:978 0761423348, 2006 Pages: 144.

[6] World Health Organization, www.who.int/water_sanitation.health/publicationns/facts2004/ enindex.html. 2004 Downloaded February 2015. 
[7] B.O. Offem, Y. Akegbejo - Samson, I.T. Omoniyi, and G.U. Ikpi, Dynamics of the limnological features and diversity of zooplankton populations of the Cross River System SE Nigeria. Knowledge and Management of Aquatic Ecosystems, 2008, 393, $2-19$.

[8] A.A Adebisi, The physico-chemical hydrology of tropical seasonal river upper Ogun River. Hydrobiologia, 1981, 79, 157 - 165. http://dx.doi.org/10.1007/BF00006123.

[9] W.A. Wurts and R.M. Durborow, Interactions of $\mathrm{pH}$, Carbon Dioxide, Alkalinity and Hardness in Fish Ponds. SRAC Publication No. 464 December 1992 4p Retrieved April 12, 2015.
[10] D. Chapman, Water Quality Assessment. A Guide to the use of Biota, Sediments and Water in Environmental Monitoring. $1^{\text {st }}$ Edn. Cambridge University Press, Cambridge, 1992 Pages 585.

[11] R.C. Engle, Aquaculture Economics and Financing: Management and Analysis. Blackwell Publication. Iowa, USA (Electronic version) 2010. 